\title{
Effect of ractopamine on Nile tilapia in the end of grow-out period
}

\section{Aldo Tovo Neto ${ }^{1 *}$, Alis Correia Bittarello ${ }^{1}$, Rogério Paulo Tovo ${ }^{2}$, Fábio Meurer ${ }^{3}$, Lilian Dena dos Santos ${ }^{4}$, Robie Allan Bombardelli ${ }^{1}$}

\footnotetext{
1 Universidade Estadual do Oeste do Paraná, Programa de Pós-graduação em Recursos Pesqueiros e Engenharia de Pesca, Toledo, PR, Brazil. ${ }_{2}^{2}$ Médico veterinário autônomo, Campo Mourão, PR, Brazil.

${ }^{3}$ Universidade Federal do Paraná, Jandaia do Sul, PR, Brazil.

${ }^{4}$ Universidade Federal do Paraná, Programa de Pós-graduação em Aquicultura e Desenvolvimento Sustentável, Palotina, PR, Brazil.
}

\begin{abstract}
This experiment was conducted in outdoor tanks to evaluate the effect of inclusion of ractopamine at increasing levels $\left(0,4,8,12\right.$, and $\left.16 \mathrm{mg} \mathrm{kg}^{-1}\right)$ as additive in Nile tilapia (Oreochromis niloticus) diet in the final grow-out period (750-920 g) during 31 days. Therefore, 400 fish were housed into 20 experimental tanks, in a completely randomized design with five treatments and four replications. Growth performance, body yield, and chemical composition of fish muscle and organs were evaluated. Fish fed diets containing up to $16 \mathrm{mg} \mathrm{kg}^{-1}$ of ractopamine for 31 days did not improve growth or performance parameters. However, lipid percentage of abdominal muscle was different in fish fed ractopamine, reaching the lowest level of $199.3 \mathrm{~g} \mathrm{~kg}^{-1}$ of ether extract at $8 \mathrm{mg} \mathrm{kg}^{-1}$ treatment. Other body chemical composition parameters did not differ between animals treated or not treated. Feeding ractopamine up to 31 days has limited effect on body composition in Nile tilapia ( $\sim 900 \mathrm{~g}$ ), without any changes in growth parameters. This is a lower metabolic response in this species when compared with mammals and other terrestrial animals.
\end{abstract}

Key Words: beta-adrenergic, feed additive, fish nutrition, growth promoters

\section{Introduction}

Nile tilapia is one of the most important species for aquaculture in several countries and its global production has been growing in various production systems (Furuya et al., 2010). It is among the most studied commercial fish species in the areas of reproduction, handling, and nutrition due to its importance.

The excess of carcass fat deposition tends to be a problem in fast-growing fish species, since it may reduce the quality and shelf life of the products (Vandenberg and Moccia, 1998) by lipid oxidation, whose man effect is the modification of the original flavor and occurrence of smell and taste rancidness (Silva et al., 1999). And although it is not considered a species with high fat deposition, tilapia can deposit more visceral fat when receiving unbalanced diets.

Received: May 22, 2016

Accepted: March 16, 2017

*Corresponding author: aldotovo@gmail.com

http://dx.doi.org/10.1590/S1806-92902017000500001

How to cite: Tovo Neto, A.; Bittarello, A. C.; Tovo, R. P.; Meurer, F.; Santos, L. D. and Bombardelli, R. A. 2017. Effect of ractopamine on Nile tilapia in the end of grow-out period. Revista Brasileira de Zootecnia 46(5):367-373.

Copyright (C 2017 Sociedade Brasileira de Zootecnia. This is an Open Access article distributed under the terms of the Creative Commons Attribution License (http://creativecommons.org/licenses/by/4.0/), which permits unrestricted use, distribution, and reproduction in any medium, provided the original work is properly cited.
Based on that, the utilization of feed additives as metabolic modifiers can reduce fat deposit in several animal tissues, in addition to other benefits in performance characteristics. Thus, in this context, ractopamine is currently under discussion as an additive to optimize animal performance and to offer a product with better carcass quality.

Ractopamine is a $\beta$-adrenergic agonist ( $\beta \mathrm{AA}$ ) from phenylethylamine group and it has structure and pharmacological properties similar to the endogenous catecholamines: adrenaline and noradrenaline (Johnson, 2004). It is an exogenous substance often called repartitioning agent for its ability to redirect nutrients from adipose tissue and increase skeletal muscle deposition (Moody et al., 2000; Almeida et al., 2012). The nutrient redirection leads to an increased efficiency of energy use, resulting in improved growth and feed efficiency (Vandenberg et al., 1998).

Succinctly, the mechanism of action of ractopamine in adipose tissue refers to decrease on fat deposition by increasing lipolysis and reduction of lipogenesis (Bergen and Merkel, 1991; Moody et al., 2000). In protein metabolism, it may have an anabolic effect, hypertrophy of muscle fibers, and frequency changes in the type of muscle fibers (Beermann and Dunshea, 2005). Ractopamine has been tested in few species of fish, such as channel catfish (Mustin and Lovell, 1993, 1995), rainbow trout (Moccia et al., 1998; Vandenberg et al., 1998; Vandenberg and 
head, skin, and fins), fillet, abdominal muscles (ventral), body wastes (head, skin, fins, and spine), viscera (without liver), and liver from each fish were weighed.

The evaluated body yield variables were: carcass yield (CAR), residue (RES), fillet yield (FILLET), and yield of abdominal muscles (AM). Hepatosomatic index (HI) and viscerosomatic index (VI) were also calculated. Flesh chemical analyses were performed according to adapted methods from Mizubuti et al. (2009).

The results were subjected to ANOVA, at the level of $\alpha=0.05$ significance, and then to multiple comparisons of means (Tukey's test). The normality was checked using Shapiro Wilk's Test and homogeneity using Levene's Test. Statistica 7.1 software was used to perform statistical analyses.

\section{Results}

Nile tilapia responded similarly as in other experiments with fish, showing low metabolic drug response or an absence of effects. The protein and fat levels remained basically unchanged for all evaluated parameters, except for ether extract portion of the abdominal musculature (Table 2).

On the other hand, ractopamine influenced the abdominal muscle chemical composition $(\mathrm{P}<0.05)$, showing a decrease of fat percentage in the treated animals (lower value in the diet with $8 \mathrm{mg} \mathrm{kg}^{-1}$, and higher value in the control treatment), decreasing 23.3\% lipid content compared with fish receiving feed without additive. Meanwhile, fat percentage from the other tissues tested (fillet, liver, and viscera) showed a similar composition and there was no statistical difference in the percentage of crude protein, ash, and dry matter of all tissues evaluated (Table 2).

No differences were detected $(\mathrm{P}>0.05)$ on performance parameters (WG, CF, and SGR) of fish fed different inclusion levels of ractopamine and the average fish weight gain in the period was approximately $170 \mathrm{~g}$. Average values of body yield (CAR, RES, FILLET, AM, HI, and VI) were similar for all treatments (Table 3 ). This may indicate that the dosage used or experimental period adopted were not sufficient to alter the energy flow redirection for other tissues to this species.

\section{Discussion}

The present work tested the inclusion of ractopamine in Nile tilapia diets in final grow-out phase and fish weight range corresponds to the slaughter average weight practiced in Brazil. The size of animals (metabolic stage) was chosen based on the concept adopted in experiments with swine, in which the use of ractopamine for a limited period in the end of grow-out phase can improve the carcass yield and reduce the fat content of finishing pigs (Cantarelli et al., 2008; Pereira et al., 2008).

Abdominal musculature is a type of fish cut marketed in Brazil which presents high lipid content when compared with tilapia fillet. Thus, the ractopamine effect could be higher in abdominal area due to the large number of available adipocytes. One possible explanation could be because the $\beta \mathrm{AA}$ acts through its receptors directly on adipose cells,

Table 2 - Proximate composition of muscle and organs $\left(\mathrm{g} \mathrm{kg}^{-1}\right)$ of Nile tilapia fed diets containing increasing levels of ractopamine

\begin{tabular}{|c|c|c|c|c|c|c|c|}
\hline & \multicolumn{5}{|c|}{ Treatment $\left(\mathrm{mg} \mathrm{kg}^{-1}\right)$} & \multirow{2}{*}{ P-value } & \multirow{2}{*}{ SEM } \\
\hline & 0 & 4 & 8 & 12 & 16 & & \\
\hline \multicolumn{8}{|c|}{ Fillet } \\
\hline Dry matter & 237.4 & 237.4 & 232.2 & 238.4 & 234.8 & 0.5071 & 0.2525 \\
\hline Ash & 11.6 & 11.9 & 11.7 & 11.6 & 11.9 & 0.1414 & 0.0143 \\
\hline Crude protein & 190.6 & 191.1 & 193.0 & 194.7 & 196.9 & 0.7073 & 0.2610 \\
\hline Ether extract & 27.4 & 25.4 & 24.4 & 24.6 & 24.0 & 0.8631 & 0.1350 \\
\hline \multicolumn{8}{|c|}{ Abdominal muscle } \\
\hline Dry matter & 407.8 & 368.7 & 355.6 & 386 & 374.7 & 0.1651 & 1.9680 \\
\hline Ash & 8.8 & 9.1 & 9.6 & 8.4 & 8.9 & 0.1437 & 0.0432 \\
\hline Crude protein & 159.4 & 162.8 & 165.5 & 153.7 & 156.4 & 0.1973 & 0.4752 \\
\hline Ether extract & $259.9 b$ & $204.9 \mathrm{ab}$ & $199.3 \mathrm{a}$ & $249.3 \mathrm{ab}$ & $219.8 \mathrm{ab}$ & 0.0182 & 2.6859 \\
\hline \multicolumn{8}{|c|}{ Liver } \\
\hline Crude protein & 115.0 & 123.4 & 114.7 & 123.7 & 119.5 & 0.3255 & 0.4355 \\
\hline Ether extract & 34.8 & 28.9 & 28.4 & 33.9 & 34.6 & 0.8454 & 0.3194 \\
\hline \multicolumn{8}{|c|}{ Viscera } \\
\hline Crude protein & 52.0 & 55.4 & 62.9 & 55.8 & 61.6 & 0.3073 & 0.4568 \\
\hline Ether extract & 443.3 & 452.6 & 435.0 & 430.3 & 410.8 & 0.8012 & 1.5696 \\
\hline
\end{tabular}

SEM - standard error of the mean.

Means in each row followed by different letters were found to differ at the 0.05 probability level by Tukey's test. 
producing signals that control the metabolic activity of the cells (Beermann and Dunshea, 2005). In addition, the activation of the $\beta$-adrenergic receptor in the adipose tissue causes phosphorylation of the hormone-sensitive lipase, which initiates lipolysis (Mersmann, 2002; Mills, 2002). In addition, stimulation of $\beta$-adrenergic receptor also inhibits the fatty acids and triacyglicerol synthesis (Mersmann, 1998).

However, lipolysis may not be the preferred pathway to decrease fat deposition in other species fed ractopamine included in the diet, as in pigs (Almeida et al., 2012). In pigs, another action of ractopamine on fat metabolism is the promotion of lower fat accretion by reducing lipogenesis (Bergen, 2001), which could be explained by the reduction of the sensitivity on adipose tissue to insulin, as it happens in pigs under $\beta A A$ stimulation, and an evidence of lipogenesis inhibition (Mills et al., 2002). Furthermore, according to recent works focusing on lipogenic gene expression in the adipose tissue of finishing pigs, ractopamine can reduce the RNA transcription of genes related to lipid synthesis, such as sterol regulatory binding protein-1 (SREBP-1), which is a transcriptional factor that drive genes involved in the synthesis of fatty acids (Horton et al., 2003) and fatty acid synthase (Reiter et al., 2007; Halsey et al., 2011), a key enzyme involved in the synthesis of fatty acids (Ferreira et al., 2013). Although no difference was found in the weight gain between control and treatment groups during the experimental period (average of $170 \mathrm{~g}$ ) (Table 3), considering that ractopamine may have more efficacy on blocking lipogenesis instead of stimulating lipolysis (Mills et al., 2003), the animals that received ractopamine may have had a decrease of lipogenesis rate, especially at $8 \mathrm{mg} \mathrm{kg}^{-1}$ of ractopamine. This could be supported by the fat percentage difference $(\mathrm{P}<0.05)$ verified in abdominal musculature at $8 \mathrm{mg} \mathrm{kg}^{-1}$ of ractopamine (Table 2).

In this experiment, a diet formulation based on vegetable ingredients was used and the experimental diets exceeded protein content requirements for this species phase (320 $\mathrm{g} \mathrm{kg}^{-1}$ of crude protein), also reaching amino acid levels for this species in grow-out phase according to data presented by Furuya et al. (2010), which probably did not limit the effect of ractopamine on the animals (Table 1). According to Mustin and Lovell (1995), when ractopamine was offered to channel fish, it was more functional with surplus of protein ingested, because when the protein intake was restricted by its low dietary concentration or by a reduced feeding frequency, there was no improvement in weight gain.

Some researchers have shown that animal protein sources may be partly or fully replaced by plant protein sources for the Nile tilapia (Boscolo et al., 2001; Meurer et al., 2008). According to Lovell (1998), soybean meal, compared with other vegetable protein feeds, offers protein with a better amino acid profile and also provides concentration of essential amino acids suitable for fish requirements. The present work adopted a diet based on soybean and corn meal.

Despite the fact that some researches show positive results in swine receiving ractopamine supplemented with lysine (Apple et al., 2004; Pereira et al., 2008), in the case of fish, the use of ractopamine combined with amino acid supplementation is even less explored. Although HajiAbadi et al. (2010) investigated the use of ractopamine supplemented with L-carnitine and obtained better results with this association to rainbow trout, the present experiment aimed to show previously the limited effects only by the ractopamine inclusion for Nile tilapia and no other additive was associated with ractopamine.

Vandenberg and Moccia (1998) reported a protein level increase and a low fat decrease in the carcass. HajiAbadi et al. (2010), using ractopamine in rainbow trout diet, observed similar behavior for protein and lipids in rainbow trout fillet muscle. Following the same trend,

Table 3 - Performance and body yield of Nile tilapia fed diets containing increasing levels of ractopamine $\left(\mathrm{mg} \mathrm{kg}^{-1}\right)$

\begin{tabular}{|c|c|c|c|c|c|c|c|}
\hline & \multicolumn{5}{|c|}{ Treatment $\left(\mathrm{mg} \mathrm{kg}^{-1}\right)$} & \multirow{2}{*}{ P-value } & \multirow{2}{*}{ SEM } \\
\hline & 0 & 4 & 8 & 12 & 16 & & \\
\hline Weight gain (g) & 175.80 & 171.13 & 167.56 & 152.93 & 161.84 & 0.5328 & 3.9543 \\
\hline Condition factor $\left(\mathrm{g} \mathrm{cm}^{-3}\right)$ & 3.87 & 3.76 & 3.90 & 3.81 & 3.78 & 0.9298 & 0.0268 \\
\hline Specific growth rate $(\%)$ & 0.54 & 0.53 & 0.52 & 0.47 & 0.49 & 0.6052 & 0.0051 \\
\hline \multicolumn{8}{|c|}{ Body yield (g $100 \mathrm{~g}^{-1}$ ) } \\
\hline Carcass yield & 89.63 & 89.65 & 89.95 & 90.43 & 89.79 & 0.7984 & 0.1461 \\
\hline Residue & 50.34 & 51.48 & 50.91 & 51.68 & 51.51 & 0.5838 & 0.2477 \\
\hline Fillet yield & 35.14 & 34.42 & 34.66 & 34.41 & 33.75 & 0.6242 & 0.2246 \\
\hline Abdominal muscle yield & 2.78 & 3.06 & 2.93 & 2.70 & 3.05 & 0.6651 & 0.0718 \\
\hline Hepatosomatic index & 1.75 & 1.77 & 1.76 & 1.67 & 1.71 & 0.8609 & 0.0179 \\
\hline Viscerosomatic index & 8.85 & 8.00 & 8.23 & 8.15 & 8.03 & 0.3012 & 0.1551 \\
\hline
\end{tabular}

SEM - standard error of the mean. 
Mustin and Lovell (1993) observed a fat reduction in the fillet content by feeding channel catfish ractopamine. In the present study, ractopamine did not alter the profile of crude protein, dry matter, and ash for any evaluated tissue (Table 2).

The performance parameters evaluated in the present study were also similar and the average of weight gain was $170 \mathrm{~g}$ during experimental period in all treatments (Table 3). Interestingly, channel catfish presented positive response to weight gain when fed ractopamine (Mustin and Lovell 1993, 1995) and Vandenberg and Moccia (1998) reported improvement on feed efficiency of rainbow trout. Haji-Abadi et al. (2010) also reported increase of weight and SGR in juvenile rainbow trout. Following the same trend, with regard to the ractopamine influence on carcass and fish body yield, no differences were observed to Nile tilapia in the present study (Table 3). Likewise, in Hungarian carp (Cyprnus carpio), ractopamine did not modify any body yield parameters evaluated (Devens et al., 2012). However, Mustin and Lovell (1995) reported a body yield decrease and suggested it may have been caused by fat content reduction in muscle of the fish fed ractopamine. These differences probably are associated both to the type of species and the age of animals.

Another factor which seems to have effect on ractopamine response is the physiological state and the age of the animals. Bicudo et al. (2012) obtained better responses in experiments by using pacu (Piaractus mesopotamicus) fingerlings and Mustin and Lovell (1995) reported positive results when ractopamine was administered to younger animals. Vandenberg and Moccia (1998) also reported positive results with rainbow trout juveniles.

However, when used in older animals, ractopamine may have low metabolic response or even not present any effect, as shown by the present work. In this experiment, ractopamine did not improve growth parameters for that species in the end of the grow-out phase (750-920 g). Similar result was reported when ractopamine was used in larger rainbow trout (final weight 700-900 g), not modifying animal growth and carcass characteristics (Moccia et al., 1998). This possible trend of lower effects in fish is opposite to that found in experiments with terrestrial animals such as swine.

This suggests that younger fish might present better responses to ractopamine than older fish (Mustin and Lovell, 1995). Likewise, there is a possible trend suggesting that Siluriforms, such as channel catfish, have better response to ractopamine when compared with other fish species.

One aspect to consider regarding the utilization of ractopamine is that the response is not constant over time
(Almeida et al., 2012), reaching higher improvement in the beginning of supplementation and decreasing along time (Andretta et al., 2011). According to Beermann and Dunshea (2005), $\beta$-agonists are active and effective when added during short periods of time (28-42 days), close to the end of the growing period in swine. This can occur when ractopamine is provided at a constant level over long periods, as a result of down-regulation or desensitization of $\beta \mathrm{AR}$, or both (Moody et al., 2010; Almeida et al., 2012). This work adopted a 31-day experimental period based on swine experiments (Armstrong et al., 2004; Amaral et al., 2009), although the effect of desensitization can occur earlier in pigs than in fish (Vandenberg et al., 1998; Ferreira et al., 2013).

The use of $\beta$-adrenergic aiming at improvements on performance parameters in fish is still little explored when compared with other species, as pigs, for example. According to Salem et al. (2006), studies show that $\beta A A$ have less anabolic effect in fish compared with mammals and before being used in aquaculture industry, it is necessary to clarify precisely the modulation mechanism of the $\beta$-adrenergic receptor in the fish muscle metabolism.

\section{Conclusions}

Feeding ractopamine to Nile tilapia $(\sim 900 \mathrm{~g})$ up to 31 days has limited effect on body composition of abdominal muscle (fat content), with no changes on growth parameters associated, which could be due a lower response from this species to ractopamine when compared with mammals and terrestrial animals.

\section{Acknowledgments}

The first author thanks Coordenação de Aperfeiçoamento de Nível Superior (CAPES) for the masters grant.

\section{References}

Almeida, V. V.; Nuñez, A. J. C. and Miyada, V. S. 2012. Ractopamine as a metabolic modifier feed additive for finishing pigs: A review. Brazilian Archives of Biology and Technology 55:445-456.

Amaral, N. O.; Fialho, E. T.; Cantarelli, V. S.; Zangeronimo, G.; Rodrigues, P. B. and Girão, L. V. C. 2009. Ractopamine hydrochloride in formulated rations for barrows or gilts from 94 to $130 \mathrm{~kg}$. Revista Brasileira de Zootecnia 38:1494-1501.

Andretta, I.; Lovatto, P. A.; Silva, M. K.; Lehnen, C. R.; Lanferdini, E. and Klein, C. C. 2011. Relação da ractopamina com componentes nutricionais e desempenho em suínos: um estudo meta-analítico. Ciência Rural 41:186-191.

Apple, J. K.; Maxwell, C. V.; Brown, D. C.; Friesen, D. G.; Musser, R. E.; Johnson, Z. B. and Armstrong, T. A. 2004. Effects of dietary lysine and energy density on performance and carcass 
characteristics of finishing pigs fed ractopamine. Journal of Animal Science 82:3277-3287.

Armstrong, T. A.; Ivers, D. J.; Wagner, J. R.; Anderson, D. B.; Weldon, W. C. and Berg, E. P. 2004. The effect of dietary ractopamine concentration and duration of feeding on growth performance, carcass characteristics, and meat quality of finishing pigs. Journal of Animal Science 82:3245-3253.

Beermann, D. H. and Dunshea, F. R. 2005. Animal agriculture's future through biotechnology, Part 3: Metabolic modifiers for animal production. Council for Agricultural Science and Technology (Ames, IA) 30:1-12.

Bergen, W. G. and Merkel R. A. 1991. Body composition of animal treated with partitioning agents: implications for human health. Faseb Journal 5:2951-2957.

Bergen, W. G. 2001. The role of cAMP elevating agents and somatotropin on pre- and posttranslational regulation of lipogenesis and lipolysis in Bos taurus and Sus scrofa. Recent Research Developments in Lipids 5:47-59.

Bicudo, A. J. A.; Sado, R. Y. and Cyrino, J. E. P. 2012. Growth, body composition and hematology of juvenile pacu (Piaractus mesopotamicus) fed increasing levels of ractopamine. Brazilian Journal of Veterinary and Animal Science 64:1335-1342.

Boscolo, W. R.; Hayashi, C.; Meurer, F. and Soares, C. M. 2001. Farinha de peixe, carne e ossos, visceras e crisalidas como atractantes em dietas para alevinos de tilápias do Nilo (Oreochromis niloticus). Revista Brasileira de Zootecnia 30:539-545.

Boscolo, W. R.; Hayashi, C. and Meurer, F. 2002. Digestibilidade Aparente da Energia e Nutrientes de Alimentos Convencionais e Alternativos para a Tilápia do Nilo (Oreochromis niloticus, L.). Revista Brasileira de Zootecnia 31:539-545.

Cantarelli, V. S.; Zangeronimo, M. G.; Almeida, E. C.; Wolp, R. C.; Pereira, L. M. and Fialho, E. T. 2008. Qualidade de cortes de suínos recebendo ractopamina na ração em diferentes programas alimentares. Acta Scientiarum Animal Science 30:165-171.

Devens, M. A.; Lazzari, R.; Rotilli, D. A.; Pucci, L. E. A.; Veiverberg, C.A. and Coldebella, I. J. 2012. Ractopamina na dieta da carpa húngara (Cyprinus carpio) criadas em tanques-rede. Brazilian Journal of Veterinary and Animal Science 64:1717-1722.

Dugan, S. G.; Lortie, M. B.; Nickerson, J. G. and Moon, T. W. 2003. Regulation of the rainbow trout (Oncorhynchus mykiss) hepatic $\beta_{2}$-adrenoceptor by adrenergic agonists. Comparative Biochemistry and Physiology Part B 136:331-342.

Ferreira, M. S. S.; Garbossa, C. A. P.; Oberlender, G.; Pereira, L. J.; Zangeronimo, M. G.; Sousa, R. V. and Cantarelli, V. S. 2013. Effect of ractopamine on lipid metabolism in vivo - a systematic review. Brazilian Archives of Biology and Technology 56:35-43.

Furuya, W. M.; Pezzato, E. P.; Barros, M. M.; Boscolo, W. R.; Cyrino, J. E. P.; Furuya, V. R. B. and Feiden, A. 2010. Tabelas brasileiras para a nutrição de tilápias. Ajinomoto Animal Nutrition, São Paulo.

Haji-Abadi, S. M. A.; Soofiani, N. M.; Sadeghi, A. A.; Chamani, M. and Riazi, G. H. 2010. Effects of supplemental dietary L-carnitine and ractopamine on the performance of juvenile rainbow trout, Oncorhynchus mykiss. Aquaculture Research 41:1582-1591.

Halsey, C. H. C.; Weber, P. S.; Reiter, S. S.; Stronach, B. N.; Bartosh, J. L. and Bergen, W. G. 2011. The effect of ractopamine hydrochloride on gene expression in adipose tissue of finishing pigs. Journal of Animal Science 89:1011-1019.

Horton, J. D.; Shah, N. A.; Warrington, J. A.; Anderson, N. N.; Park, S. W.; Brown, M. S. and Goldstein, J. L. 2003. Combined analysis of oligonucleotide microarray data from transgenic and knockout mice identifies direct SREBP target genes. PNAS 100:12027-12032.

Johnson, B. 2004. Efficacy, mode of beta-adrenergic agonist discussed. Feedstuffs 76:13-17.
Kraemer, F. B. and Shen, W. J. 2002. Hormone-sensitive lipase: control of intracellular tri-(di)-acylglycerol and cholesteryl ester hydrolysis. Journal of Lipid Research 43:1585-1594.

Lortie, M. B.; Arnason, T.; Dugan, S. G.; Nickerson, J. G. and Moon, T. W. 2004. The impact of feeding $\beta_{2}$-adrenergic agonists on rainbow trout muscle $\beta$-adrenoceptors and protein synthesis. Journal of Fish Biology 65:769-787.

Lovell, T. 1998. Nutrition and feeding of fish. Kluwer Academic Publishers, Boston.

Mersmann, H. J. 1998. Overview of the effects of beta-adrenergic receptor agonists on animal growth including mechanisms of action. Journal of Animal Science 76:160-172.

Mersmann, H. J. 2002. Beta-Adrenergic receptor modulation of adipocyte metabolism and growth. Journal of Animal Science 80: E24-E29.

Meurer, F.; Hayashi, C.; Barbero, L. M.; dos Santos, L. D.; Bombardelli, R. A. and Colpini, L. M. S. 2008. Farelo de soja na alimentação de tilápia-do-Nilo durante o período de reversão sexual. Revista Brasileira de Zootecnia 37:791-794.

Mills, S. E. 2002. Biological basis of the ractopamine response. Journal of Animal Science 80(E. Suppl. 2):28-32.

Mills, S. E.; Spurlock, M. E. and Smith, D. J. 2003. $\beta$-Adrenergic receptor subtypes that mediate ractopamine stimulation of lipolysis. Journal of Animal Science 81:662-68.

Mizubuti, I. Y.; Pinto, A. P.; Pereira, E. S. and Ramos, B. M. O. 2009. Métodos laboratoriais de avaliação de alimentos para animais. EDUEL, Londrina.

Moccia, R. D.; Gurure, R. M.; Atkinson, J. L. and Vandenberg, G. W. 1998. Effects of repartitioning agent ractopamine on the growth and body composition of rainbow trout, Oncorhynchus mykiss (Walbaum), fed three levels of dietary protein. Aquaculture Research 29:687-694.

Moody, D. E.; Hancock, D. L. and Anderson, D. B. 2000. Phenethanolamine repartitioning agents. p.65-95. In: Farm animal metabolism and nutrition. D'Mello, J. P. F., ed. CAB International, New York, USA.

Mustin, W. T. and Lovell, R. T. 1993. Feeding the repartitioning, ractopamine, to channel catfish (Ictalurus punctatus) increases weight gain and reduces fat deposition. Aquaculture 109:145-152.

Mustin, W. T. and Lovell, R. T. 1995. Dietary protein concentration and daily feed allowance influence response of channel catfish, Ictalurus punctatus (Rafinesque) to ractopamine. Aquaculture Nutrition 1:21-26.

Oliveira, L. M. F. S.; Leal, R. S.; Mesquita, T. C.; Pimenta, M. E. S. G.; Zangeronimo, M. G.; Sousa, R. V. and Alvarenga, R. R. 2014. Effect of ractopamine on the chemical and physical characteristics of pacu (Piaractus mesopotamicus) steaks. Arquivo Brasileiro de Medicina Veterinária e Zootecnia 66:185-194.

Pereira, F. A.; Fontes, D. O.; Silva, F. C. O.; Ferreira, W. M.; Lanna, A. M. Q.; Corrêa, G. S. S.; Silva, M. A.; Marinho, P. C.; Arouca, C. L. C. and Salum, G. M. 2008. Efeitos da ractopamina e de dois níveis de lisina digestível na dieta sobre o desempenho e características de carcaças de leitoas em terminação. Arquivo Brasileiro de Medicina Veterinária e Zootecnia 60:943-952.

Reiter, S. S.; Halsey, C. H. C.; Benjamin, M. S.; Bartosh, J. L.; Owsley, W. F.; Bergen, W. G. 2007. Lipid metabolism related geneexpression profiling in liver, skeletal muscle and adipose tissue in crossbred Duroc and Pietrain pigs. Comparative Biochemistry and Physiology, Part D 2:200-206.

Salem, M.; Levesque, H.; Moon, T. W.; Rexroad, C. E. and Yao, J. 2006. Anabolic effects of feeding $\beta 2$-adrenergic agonists on rainbow trout muscle proteases and protein. Comparative Biochemistry and Physiology Part A 144:145-154.

Silva, D. J. F. A. M.; Borges, M. F. M. and Ferreira, M. A. 1999. Métodos para avaliação do grau de oxidação lipídica e da capacidade oxidante. Química Nova 22:94-103. 
Vandenberg, G. W.; Leatherland, J. F. and Moccia, R. D. 1998. The effects of the beta-agonist ractopamine on growth hormone and intermediary metabolite concentrations in rainbow trout, Oncorhynchus mykiss (Walbaum). Aquaculture Research 29:79-87.
Vandenberg, G. W. and Moccia, R. D. 1998. Growth performance and carcass composition of rainbow trout, Oncorhynchus mykiss (Walbaum), fed the $\beta$-agonist ractopamine. Aquaculture Research 29:469-479. 